\title{
EVALUATION OF SOME FACTORS INFLUENCING GROWTH PERFORMANCE OF LOCAL GOATS IN NIGERIA
}

\author{
Zahraddeen $\mathrm{D}^{* 1}$, ISR Butswat ${ }^{1}$ and ST Mbap ${ }^{1}$
}

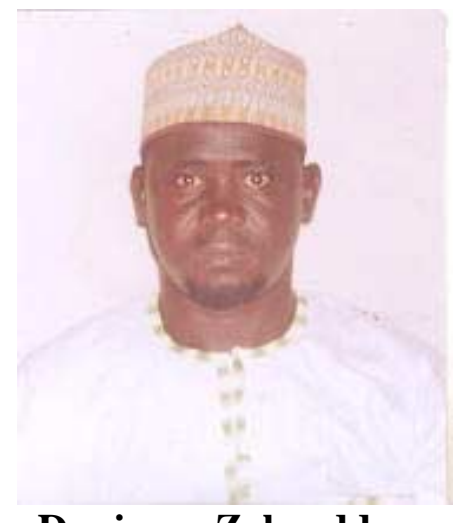

\section{Danjuma Zahraddeen}

*Corresponding author e-mail: zdzariya@yahoo.com

${ }^{1}$ Animal Production Programme, School of Agriculture and Agricultural Technology, Abubakar Tafawa Balewa University, P.M.B.0248, Bauchi, Nigeria 


\section{ABSTRACT}

This study was conducted at the Research Farm of the Abubakar Tafawa Balewa University, Bauchi, Nigeria to investigate some factors (breed, season, parity, sex, litter size and body condition score) affecting kids' growth performance at various ages. The daily weight gain (overall) of kids reveals non-significant breed effect whereas season, parity, sex, litter size and body condition score had significant $(\mathrm{P}<0.05)$ effects on the kids' daily weight gain. Kids born in the dry season had higher daily weight gain $(98.95 \pm 4.65 \mathrm{~g})$ than those born in the wet season $(88.15 \pm 5.31 \mathrm{~g})$. Similarly, kids born in the second $(90.58 \pm 3.71 \mathrm{~g})$ and third $(88.28 \pm 11.31 \mathrm{~g})$ parities gained higher weights daily than kids in the first $(86.80 \pm 3.25 \mathrm{~g})$ parity. There were significant $(\mathrm{P}<0.05)$ sex and litter size effects on kids' daily weight gain. The male kids had higher daily weight gain than their female counterparts with respective values of $92.94 \pm 5.06$ and $84.16 \pm 5.46 \mathrm{~g}$. Similarly, kids born single gained higher $(90.06 \pm 4.03 \mathrm{~g})$ daily weights than those born as twins $(87.04 \pm 6.58 \mathrm{~g})$. Kids from does with body condition score 4 had the highest $(91.61 \pm 6.61 \mathrm{~g})$ daily weight gain followed by $3(89.37 \pm 5.37 \mathrm{~g})$ and least value was observed in does with score 2 $(84.67 \pm 4.95 \mathrm{~g})$. Kids' weights at various ages (birth, 30, 60, 90 and 120 days) showed significant $(\mathrm{P}<0.05)$ differences except for the effects of litter size (at birth, 60,90 and 120 days) and sex (at 30, 60 and 120 days of life). Similarly, kids' mean daily weight gains at various age intervals (birth - 30, 31- 60, 61- 90 and 91- 120 days) also showed significant $(\mathrm{P}<0.05)$ differences in these factors except for the effects of breed (at 61-90 days), sex (at birth - 60 days), litter size ( 61-10 days) and parity ( 31-120 days of life). It is, therefore, concluded that large body size, good body condition, dry season, birth of male kid and single birth and high parity resulted in higher postnatal kid weight and daily weight gain. The Sahel goats are more promising than the other breeds in terms of their growth performance. Improvement of these breeds can be made through crossbreeding with better local or exotic breed. However, these local breeds can be successfully used for quality meat production and supply at an early stage of their life.

Key words: Goats, age, daily weight gain 


\section{INTRODUCTION}

Indigenous goats in Nigeria belong to three distinct breeds. The long-legged Sahel found in the arid and Sahel regions, the relatively small body-sized Red Sokoto found in the savanna zone and the hardy, short-legged West African Dwarf restricted to high altitude areas and humid forest of the south $[1,2]$. Virtually all these breeds are found in Bauchi State, the study area. The Red Sokoto had the highest population followed by the West African Dwarf and Sahel with least population [3]. The State being located in the savanna zone the ecological niche of Red Sokoto. It is, therefore, expected that the population of Red Sokoto goats will be high. The population of West African Dwarf increases from the drier to wetter parts of the State. Conversely, the Sahel goat population increases as one tended towards the desert or drier parts of the State.

The breeding characteristics of these animals in Bauchi are well documented in the literature $[4,5,6]$. It has been reported that parameters such as litter size, birth weight and growth rate of offspring from birth to weaning are some indices of reproductive performance [7]. The reproductive function and capacity of goats in the tropics are affected by several factors such as nutrition [8], season [3, 9], genotype [5, 10] and diseases $[10,11]$. It has been shown that the low reproductive performance of these animals in north-eastern Nigeria is implicated to the traditional husbandry system, where no special care is given to the breeding stock and hence their performance remains perpetually low [5].

However, the productivity of the indigenous goats is generally low with respect to growth and lactation performance. It is therefore imperative to understand and improve the growth performance of these animals in this country in order to form a basis for rapid controlled breeding programme. It is also necessary that any breeding programme should always include the indigenous breeds since they possess some innate resistance to certain local diseases in addition to adaptability to prevailing climatic conditions. Improvement in these animals would go a long way towards increased sources of quality and quantity meat and milk, which provide animal protein that is indispensable to a balanced human diet. It has been reported that goat meat or chevon is widely accepted in the country and has wide acceptability among the different socio-cultural groups because there is a lack of taboo against chevon [12]. It has also been reported that the milk from goats has special characteristics such as high digestibility, distinct alkalinity and therapeutic uses in medicine [13]. For instance, goat milk has been shown to be tolerated by children and infants suffering from hypersensitivity to cow milk [14]. However, the small size of goats relative to cattle and other farm animals contributes to their wide distribution and ease of management among women and children who provide the bulk labour in small family farms [15]. Goats have important drought survival strategy in marginal cropping areas where mixed farming is prevalent [16]. Also, goats serve as an insurance against crop failure because they are liquid asset [15].

Performance of these three recognized indigenous goats with respect to differences in breed, body condition score, season, sex, litter size and parity is practically non-

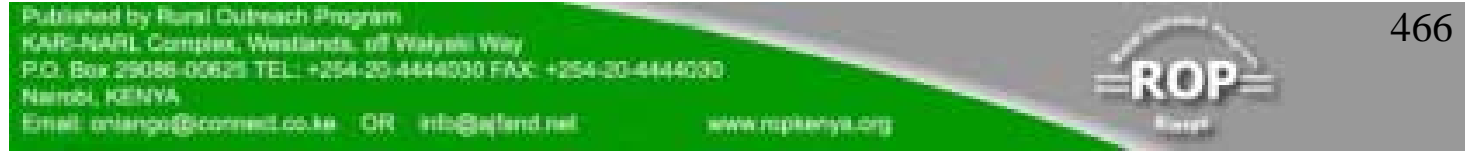




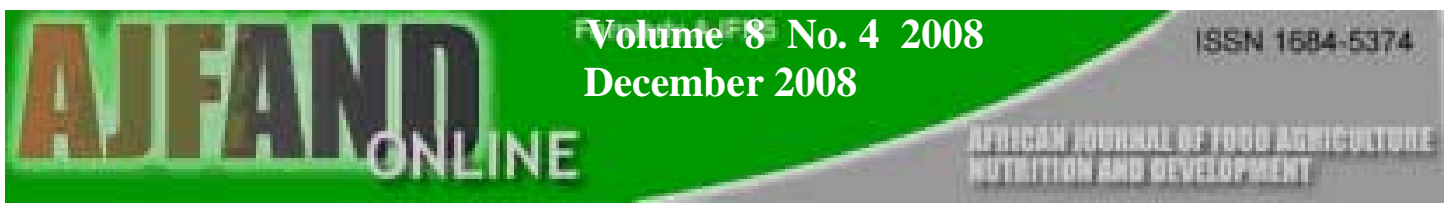

existent in literature. Therefore, this study was designed to investigate the pattern of growth and development in these species in Bauchi with the hope of providing baseline information for improvement in their growth traits.

\section{MATERIALS AND METHODS}

\section{Location and climate}

Bauchi metropolis, the study area, apart from being the State capital and headquarters of Bauchi Local Government, is also the main urban centre in the State. It is situated on latitude $10^{0} 17^{\mathrm{I}}$ north, longitude $8^{0} 49^{\mathrm{I}}$ east and at an altitude of 690.2 metres above sea level in the northern guinea savannah ecological zone of Nigeria [17].

\section{Experimental goats}

The breeds of goat used for the study were the Red Sokoto (RS), Sahel (SG) and West African Dwarf (WAD). A total of 43 goats including two bucks per breed constituted the initial stock. The bucks were used for within breed natural mating on the nulliparous does aged one-year. The composition of does at the beginning of fertility trial was $15 \mathrm{RS}, 12 \mathrm{SG}$ and $10 \mathrm{WAD}$. These does were used to produce the offspring (kids) on which records were taken.

\section{Goat management}

The animals were managed semi-intensively. In the night, they were kept in crossventilated pens within the animal house but allowed to graze during the day within the University premises. They were supplemented with mineral licks and concentrate; a mixture of poultry litter, maize offal and rice bran in 1:2:1 ratio (18\% crude protein). At times they were also fed groundnut haulms. Routine health care practices such as vaccination/medication, ecto-parasite control and de-worming were also regularly carried out. Fresh drinking water was provided ad libitum. The animals were also kept for three weeks to acclimatize before the commencement of the study.

\section{Data collection}

Data for this study were collected on-station from October 2003 to May 2006. The age of the goats was determined by dentition method as reported by Butswat [4]. Does and their kids were weighed using a bathroom scale. Body condition score was also determined as per the procedures laid down by Jefferies [18]. Breeding was monitored up to third parity using within breed mating. All does were hand-mated. Kids' weights at various ages $(0,30,60,90$ and 120 days) and the dam's parity were recorded. Growth rates from birth to 30, 31 - 60, $61-90$ and $91-120$ days of life were also determined using the following relationship reported by Malau-Aduli et al. [19].

$$
\text { Growth rate }=\frac{\text { Final body weight }- \text { Initial body weight }}{\text { Number of days }}
$$

\section{Data analysis}

The data generated were subjected to analyses of variance, correlation and regression using the General Linear Model (GLM) of SPSS (2001). Means were subsequently

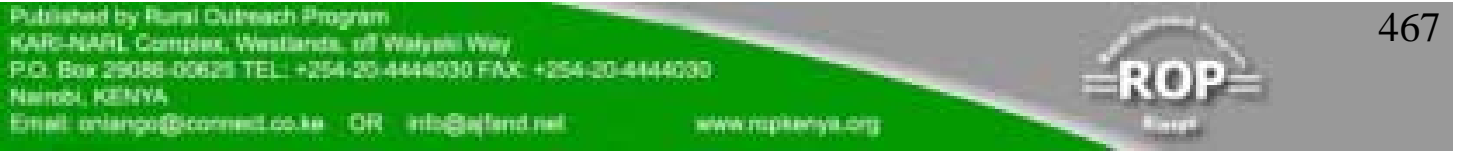




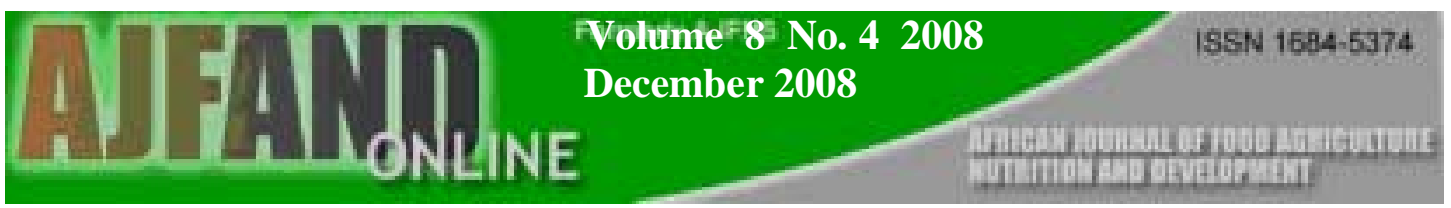

separated using Duncan Multiple Range Test (DMRT) method described by Humburg [20].

\section{RESULTS}

The daily weight gain of kids reveals non-significant breed effect whereas season, parity, sex, litter size and body condition score had significant $(\mathrm{P}<0.05)$ effects on the kids' daily weight gain. Kids born in the dry season had higher daily weight gain $(98.95 \pm 4.65 \mathrm{~g})$ than those born in the wet season $(88.15 \pm 5.31 \mathrm{~g})$. Similarly, kids born in the second $(90.58 \pm 3.71 \mathrm{~g})$ and third $(88.28 \pm 11.31 \mathrm{~g})$ parities gained higher weights daily than kids in the first $(86.80 \pm 3.25 \mathrm{~g})$ parity. Kids from does with body condition score 4 had the highest $(91.61 \pm 6.61 \mathrm{~g})$ daily weight gain followed by 3 $(89.37 \pm 5.37 \mathrm{~g})$ and least value was observed in does with score $2(84.67 \pm 4.95 \mathrm{~g})$. There were significant $(\mathrm{P}<0.05)$ sex and litter size effects on kids' daily weight gain. The male kids had higher daily weight gain than their female counterparts; with respective values of $92.94 \pm 5.06$ and $84.16 \pm 5.46 \mathrm{~g}$. Similarly,kids born single gained higher $(90.06 \pm 4.03 \mathrm{~g})$ daily weights than those born as twins $(87.04 \pm 6.58 \mathrm{~g})$ (Table $1)$.

Kids weights at various ages (birth, 30, 60, 90 and 120 days) as influenced by breed, body condition score, season, sex, litter size and parity are shown in Table 2.The SG does had the largest weight at birth $(1.91 \pm 0.01 \mathrm{~kg})$ followed by RS $(1.76 \pm 0.01 \mathrm{~kg})$ which were significantly $(\mathrm{P}<0.001)$ higher than that of WAD $(1.65 \pm 0.01 \mathrm{~kg})$. This superiority was maintained through $30,60,90$ and 120 days of age .The weight superiority as applied to kids from does with different body condition scores were (4> $3>2)$, parity $(3>2>1)$ and season (in favour of the dry season). These superiorities $(\mathrm{P}<0.001)$ were sustained up to day 120 of age. However, while male kids were superior $(\mathrm{P}<0.05)$ at birth, at 30 and 60 days there was similarity in the weight of the two sexes. At 90 days of age male kids were again heavier then and there was similarity in weight gain at 120 days. The influence of litter size at birth on kid weights differed non-significantly but at the age of 30 days kids born single became significantly $(\mathrm{P}<0.05)$ heavier than twins.

Kids mean daily weight gains (growth rates) at various age interval (birth to 30, 3160, 61-90 and 91-120 days) as influenced by breed, body condition score, season, sex, litter size and parity are presented in Table 3 . The results show that daily weight gain was significantly affected by breed from birth to 30 day $(\mathrm{P}<0.01), 31-60$ days $(\mathrm{P}<0.05)$ of age. The RS and SG kids were superior to their WAD counterparts during these intervals. However, during 61-90 days the three breeds did not differ significantly, but from 91 to 120 days the RS kids were superior $(\mathrm{P}<0.01)$ to $\mathrm{SG}$ and WAD kids. The does' body condition scores had pronounced effect on daily weight gain of kids at the various age intervals. For instance, kids from does with body condition scores 3 and 4 were superior $(\mathrm{P}<0.05)$ to kids from does with score 2 at birth to 30, 31- 60 and 91-120 days of age. However, there was significant $(\mathrm{P}<0.05)$ seasonal influence on kids daily weight gain at birth to 30 and 91- 120 days of age only; with kids born in the dry season being favoured. Similarly, male kids were only significantly $(\mathrm{P}<0.05)$ better than their female counterparts at 61-90 $(\mathrm{P}<0.01)$ and 91 - 
$120(\mathrm{P}<0.05)$ days of age as shown in Table 3. Kids born single gained more weight daily than twins at birth to 30 and 31-60 days of age $(\mathrm{P}<0.05)$. There was, however, no significant difference in the daily weight gains of kids born single or twins from 61 to 120 days of life. Conversely, kids from second and third parities were superior $(\mathrm{P}<0.001)$ to their counterparts in daily weight gain only from birth to 30 days of age.

There were significant correlations $(\mathrm{P}<0.05-\mathrm{P}<0.001)$ between some of the goat traits and daily weight gain of kids. For instance, there were high and positive correlations between litter size versus body condition score $(\mathrm{r}=0.25)(\mathrm{P}<0.05)$, age versus weight $(\mathrm{r}=0.97)$, age versus daily weight gain $(\mathrm{r}=0.63)(\mathrm{P}<0.01)$. However, there were also low and negative correlations between litter size versus weight $(r=-$ $0.12)$, litter size versus daily weight gain $(\mathrm{r}=-0.12)(\mathrm{P}<0.05)$ and weight versus daily weight gain $(\mathrm{r}=-0.50)(\mathrm{P}<0.01)$. Table 4 shows the regression equations of weight and daily weight gain versus age in the three breeds. In RS, SG and WAD goats, the variations in weight of kids due to age were 95.3, 95.2 and 94.6\% respectively. Similarly, the variations in daily weight gain of kids due to age were 28.0, 52.6 and $41.8 \%$ for RS, SG and WAD respectively.

\section{DISCUSSION}

The initial kid weight (birth weight) observed in this study is higher than the values reported by Adama and Arowolo [21] in Savanna Brown kids but lower than the findings of Nkungu et al.[22] in Norwegian goats and their crosses in Tanzania. This study also observed significant breed effect on kid weight at various ages. The SG kids had the highest initial weight followed by RS. The weight superiority was maintained at various ages up to weaning age (4 months). Superiority in growth performance of RS over WAD kids at 12 month of age had been reported [23]. Superiority from 75 and 50\% Norwegian crosses as compared to 100 and $87.5 \%$ Norwegians had been observed by Nkungu et al.[22]. Superior weight in RS $(11.53 \mathrm{~kg})$ over WAD $(8.78 \mathrm{~kg})$ kids at weaning and attributed it to genotype as observed in the study reported by Butswat et al. [5].

Kids from does with good body conditions tended to be superior in weight during all stages of life. It has similarly been observed by Malik et al.[24] that weight of does at kidding influenced kids birth weights positively. It has also been reported that weight of kids at weaning was significantly higher $(6.53 \mathrm{~kg})$ in does with body condition score 2 than those with body condition score $1(3.05 \mathrm{~kg})[25]$.

Kids born in the dry season were superior to their counterparts in the wet season in terms of initial weight. This weight advantage was consistently maintained up to the weaning age of four months. This superiority is mainly attributed to the fact the wet season is characterized by many growth-limiting factors; the restriction imposed due to farming activities, high incidence of pests and diseases and the interplay and influence of climatic factors. It has also been observed that climatic factors influence greatly the productivity of goats especially under traditional system of management through their effects, principally on forage, water availability, thermal stress and photoperiod which are reflected in seasonal trends in growth, reproduction and

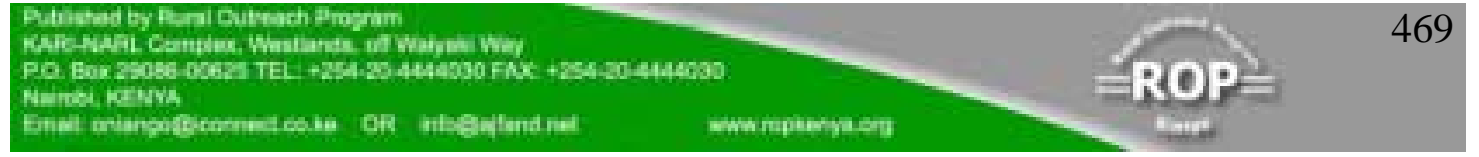


morbidity [4]. However, it is reported that kids survived best and weaned at 3 months after birth during the dry season [25]. This difference was probably attributed to fewer incidences of pests and diseases in the dry than in wet season. It has also been observed that weaner does fed concentrate at $2 \%$ of body weight attained puberty at earlier ages and heavier body weight than does fed concentrate at $1 \%$ body weight [19]. These workers also stated that the purpose of proper management of a young male animal is to improve growth performance and to enable them produce optimum levels of good quality semen at the earliest possible age.

Male kids weighed more than females kids at birth and were heavier at various ages up to 120 days. This agrees with the findings of Nkungu et al.[22] who observed that male kids were superior to their female counterparts at all stages of growth up to 12 months. Similarly, the male kids of Savanna Brown goats had consistent weight advantage over the females at various ages up to 100 days [21]. It has been attributed that the growth superiority of male kids to higher birth weight and presence of androgens, which play a role in growth $[22,26]$. These workers further stated that the superiority may also be due to the fact that males are more aggressive and active than females, and may consume more milk and feed. The difference between male and female kids may also be reflected in attainment of puberty. It has been observed that the onset of puberty is more closely related to body weight than age [27]. This means that male or female kids from SG goats may reach puberty at relatively younger age than the other indigenous goat breeds of the same sex and other management practices.

The study observed that kids born single were non-significantly heavier than their twin counterparts (at 30 days of age and thereafter) the non-significant difference resumed. The growth performance of kids born single was higher than twins at various ages $[28,29]$. These workers attributed the weight advantage to competition for nutrients (milk) and the less inter-uterine space in cases where does carry two or more foetuses as compared to one.

This study observed that kids from lower parities had significantly lower weights at different ages, than third parity kids. This superiority was consistently maintained up to weaning at 120 days of age. This might have been due to increase in doe body weight with advance in parity or age, which reflected on kids. It has been similarly observed by Bemji et al. [30] that live weight of kids significantly increased with parity of does.

The RS and SG were similar in daily weight gains, but significantly higher than WAD at the various age intervals. Significant (growth rate) daily weight gain difference at various ages of Norwegian kids crosses (100, 87.5, 75 and 50\%) have been reported, and was attributed to inherent live weight differences [22].

Kids from does with good body condition score had significantly higher daily weight gain at various ages than those with lower body scores. Good body condition is a reflection of good nutrition and hence adequate body tissue reserves for normal functions of the body. Nutrition has a great influence on the reproductive performance

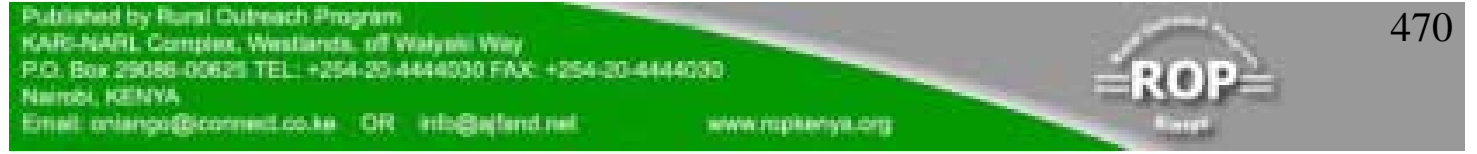


of sheep, which differ, to some extent from goats [31]. It has been shown that parameters such as litter size, birth weight and growth rate of offspring from birth to weaning are indices of reproductive performance [7].

This study observed that the dry season kids had significantly higher daily weight gain than wet season kids from birth to 30 days of age, and subsequently (from 31-90 days) there was non-significant difference until 91-120 days of age when the wet season kids had significant weight advantage over the dry season counterparts. This difference in the daily weight gain of dry and wet season kids might have been due to the dynamics of feed or nutrient supply and availability to the animals and their freedom to roam and fend for themselves. It has been reported that the weights of goats were highest during the early rainy seasons, while the least weights were obtained during the late rainy season [4].

The study observed non-significant sex effect on daily weight gain of kids from birth up to 60 days of age. A similar observation has been made by [21] in Savanna Brown kids from birth to 100 days of age. The finding of this study however contradicts the findings of [22] who reported that female kids had higher daily weight gain from birth to 3 months of age. The present study observed significant sex effect on daily weight gain from 61-120 days in favour of male kids. This agrees with the observation made by Nkungu et al.[22] that there was consistently higher weight gain advantage in male than in female kids from 3 to 12 months of age.

Significant litter size effect was observed on daily weight gain of kids from birth to 60 days of age and in favour of kids born single. This contradicts an earlier study by Adama and Arowolo[21] that single male, single female, twin male and twin female kids differed non-significantly in terms of daily weight gain from birth to 100 days of age. However, this study agrees with the reports by Nkungu et al. [22] that kids born single were superior to their counter parts born twins in daily weight gain from birth to 12 months of age. The consistent daily weight gain advantage (in favour of kids born single) may be linked to pre-and-early post-natal nutrient competition and the less inter-uterine space the twin kids experienced.

Significant parity effect was also observed in the study with respect to kids daily weight gain. From birth to 30 days of age, the daily weight gain increased significantly with parity, and subsequently (from 31 to 120 days) the difference remains unchanged statistically in the three parities. This observation could be linked to the explanations given by Bemji et al.[30] that live-weight of does increased significantly with parity which reflected on the birth weights of their kids. This should also have effect on their early growth rate.

Some prediction equations obtained in this study were significant and had large coefficient of multiple determination $\left(\mathrm{R}^{2}\right)$. The high percentage $\mathrm{R}^{2}$ - are indications that the weight changes of kids were mainly attributed to age. On the other hand, the lower percentages $\mathrm{R}^{2}$-values are indications that a lot of the variations in kids daily weight gain were due to other causes. That is, the high $\mathrm{R}^{2}$-values for some equations indicate their ability to predict kid body weights and daily weight gains at various 
ages accurately as opposed to low $\mathrm{R}^{2}$ values. A similar report has been made by Akanno and Ibe [32]. They further stated that this tool (regression equations) could be valuable in some rural African farm communities where sensitive weighing scales are not readily available in the market and if available are expensive. Animal dentition could be applied to obtain age (if done accurately), which in turn could be used to predict live weight or daily weight gain.

Improvement in performance of growth traits in this species and probably in other farm animal species will help in no small measure in enhancing the protein production, supply and consumption by the populace. It has been reported that good nutrition is a prerequisite for good health, reproduction and fast growth rate in individuals [33].

\section{CONCLUSION}

Based on the results of this study on kids' growth performance, it is concluded that large body size, good body condition score, dry season, birth of male kid and single birth and high parity resulted in high post-natal kids' weight and daily weight gain. These in turn lead to increased performance in terms of improved birth and weaning weights, survival rates of kids at various ages of life and early attainment of age at puberty, improved reproductive make-up of kids at commencement of reproduction, substantial improvement in milk yield in kids that grow to does in their first and subsequent parities, increased immunity and minimal incidence of diseases and pests among kids, increased meat/protein production at an early stage of life and increased income supply of the farmer. 
Table 1: The influence of breed, body condition score, season, parity, sex and litter size on the overall kids daily weight gain

\begin{tabular}{|c|c|c|}
\hline & $\mathrm{n}$ & Daily weight gain (g) \\
\hline Overall & 288 & $88.55 \pm 4.58$ \\
\hline Breed & & NS \\
\hline Red Sokoto & 116 & $92.05 \pm 5.11$ \\
\hline Sahel & 88 & $89.92 \pm 5.80$ \\
\hline West Africar & 84 & $83.68 \pm 5.17$ \\
\hline Season & & $*$ \\
\hline Dry & 167 & $98.95 \pm 4.65^{\mathrm{a}}$ \\
\hline Wet & 121 & $88.15 \pm 5.31^{\mathrm{b}}$ \\
\hline Parity & & $*$ \\
\hline 1 & 160 & $86.80 \pm 3.25^{\mathrm{b}}$ \\
\hline 2 & 119 & $90.58 \pm 3.71^{\mathrm{a}}$ \\
\hline 3 & 9 & $88.28 \pm 11.31^{\mathrm{a}}$ \\
\hline $\operatorname{Sex}$ & & $*$ \\
\hline Male & 132 & $92.94 \pm 5.06^{\mathrm{a}}$ \\
\hline Female & 156 & $84.16 \pm 5.46^{\mathrm{b}}$ \\
\hline Litter size & & $*$ \\
\hline 1 & 239 & $90.06 \pm 4.03^{\mathrm{a}}$ \\
\hline 2 & 49 & $87.04 \pm 6.58^{b}$ \\
\hline \multicolumn{2}{|c|}{ Body condition score } & $*$ \\
\hline 2 & 120 & $84.67 \pm 4.95^{\mathrm{a}}$ \\
\hline 3 & 108 & $89.37 \pm 5.37^{\mathrm{b}}$ \\
\hline 4 & 60 & $91.61 \pm 6.61^{\mathrm{a}}$ \\
\hline
\end{tabular}




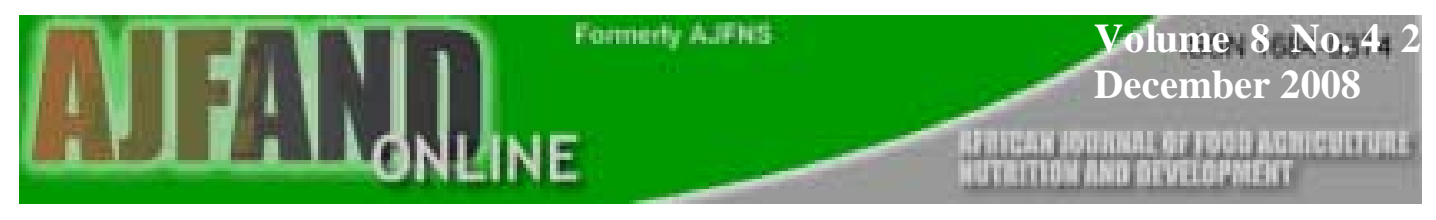

$\frac{\text { Table 2: } \quad \text { Kids mean weights }(\mathrm{kg}+\text { S.E) }) \text { at various ages by breed, body condition score, season, sex, litter size and parity }}{\text { Age (days) }}$

Table 2: $\quad$ Kids mean weights $(\mathrm{kg}+\mathrm{S}$ S.E) at various ages by breed, body condition score, season, sex, litter size and parity

$\begin{array}{lllll}-0 & 30 & 60 & 90 & 120\end{array}$

120

\begin{tabular}{|c|c|c|c|c|c|c|}
\hline Overall & 102 & $\begin{array}{l}1.77 \pm 0.01 \\
* * *\end{array}$ & $\begin{array}{l}6.37 \pm 0.06 \\
* * *\end{array}$ & $\begin{array}{l}8.19 \pm 0.05 \\
* * *\end{array}$ & $\begin{array}{l}10.48 \pm 0.06 \\
* * *\end{array}$ & $\begin{array}{l}12.40 \pm 0.06 \\
* * *\end{array}$ \\
\hline \multicolumn{7}{|l|}{ Breed } \\
\hline Red Sokoto & 29 & $1.76 \pm 0.01^{\mathrm{b}}$ & $6.47 \pm 0.08^{\mathrm{b}}$ & $8.20 \pm 0.06^{\mathrm{b}}$ & $10.33 \pm 0.0^{\mathrm{b}}$ & $12.75 \pm 0.07^{\mathrm{a}}$ \\
\hline Sahel & 22 & $1.91 \pm 0.01^{\mathrm{a}}$ & $6.61 \pm 0.09^{\mathrm{a}}$ & $8.66 \pm 0.06^{\mathrm{a}}$ & $11.04 \pm 0.09^{\mathrm{a}}$ & $12.77 \pm 0.09^{\mathrm{a}}$ \\
\hline West African Dwarf & 21 & $1.65 \pm 0.01^{\mathrm{c}}$ & $6.03 \pm 0.08^{c}$ & $7.71 \pm 0.05^{\mathrm{c}}$ & $10.08 \pm 0.08^{\mathrm{c}}$ & $11.69 \pm 0.07^{\mathrm{b}}$ \\
\hline \multicolumn{2}{|l|}{ Body condition score } & $* * *$ & $*-$ & $* * *$ & $*$ & $* * *$ \\
\hline 2 & 27 & $1.73 \pm 0.01^{\mathrm{c}}$ & $6.20 \pm 0.08^{\mathrm{b}}$ & $8.02 \pm 0.06$ & $10.36+0.07^{\mathrm{c}}$ & $12.15 \pm 0.07^{\mathrm{c}}$ \\
\hline 3 & 36 & $1.78 \pm 0.01^{\mathrm{b}}$ & $6.36 \pm 0.08^{\mathrm{a}}$ & $8.19 \pm 0.05^{\mathrm{b}}$ & $10.54 \pm 0.08^{\mathrm{b}}$ & $12.39 \pm 0.09^{\mathrm{b}}$ \\
\hline 4 & 9 & $1.81 \pm 0.01^{\mathrm{a}}$ & $6.55 \pm 0.11^{\mathrm{a}}$ & $8.36 \pm 0.08^{\mathrm{a}}$ & $10.55 \pm 0.12^{\mathrm{a}}$ & $12.68 \pm 0.10^{\mathrm{a}}$ \\
\hline \multicolumn{2}{|l|}{ Season } & $* * *$ & $* * *-$ & $* * *$ & $* * *$ & $*$ \\
\hline Dry & 39 & $1.81 \pm 0.01^{\mathrm{a}}$ & $6.54 \pm 0.07^{\mathrm{a}}$ & $8.38 \pm 0.05^{\mathrm{a}}$ & $10.72 \pm 0.07$ & $12.49 \pm 0.06^{\mathrm{a}}$ \\
\hline Wet & 33 & $1.73 \pm 0.01^{\mathrm{b}}$ & $6.20 \pm 0.08^{b}$ & $8.00 \pm 0.06^{\mathrm{b}}$ & $10.25 \pm 0.08^{\mathrm{b}}$ & $12.32 \pm 0.0 \mathrm{~b}^{\mathrm{b}}$ \\
\hline \multicolumn{2}{|l|}{ Sex } & $*$ & NS & NS & $* *$ & NS \\
\hline Male & 34 & $1.78 \pm 0.01^{\mathrm{a}}$ & $6.44 \pm 0.08$ & $8.25 \pm 0.06$ & $10.67 \pm 0.07^{\mathrm{a}}$ & $12.47 \pm 0.08$ \\
\hline \multirow[t]{2}{*}{ Female } & 38 & $1.76 \pm 0.01^{\mathrm{b}}$ & $6.30 \pm 0.08$ & $8.13 \pm 0.06$ & $10.30 \pm 0.09^{\mathrm{b}}$ & $12.34 \pm 0.08$ \\
\hline & & $\mathrm{NS}^{-}$ & $*-$ & $\mathrm{NS}^{-}$ & $\mathrm{NS}$ & NS \\
\hline \multicolumn{7}{|l|}{ Litter Size } \\
\hline 1 & 60 & $1.78+0.01$ & $6.48+0.06^{\mathrm{a}}$ & $8.21+0.04$ & $10.47 \underline{+0.05}$ & $12.46+0.05$ \\
\hline \multirow[t]{2}{*}{2} & 12 & $1.77 \pm 0.01$ & $6.26 \pm 0.10^{\mathrm{b}}$ & $8.17 \pm 0.07$ & $10.49 \pm 0.10$ & $12.35+0.11$ \\
\hline & & $* * *$ & $* * *$ & $* * *$ & $* * *$ & $* * *$ \\
\hline \multicolumn{7}{|l|}{ Parity } \\
\hline 1 & 40 & $1.72 \pm 0.01^{\mathrm{c}}$ & $5.97 \pm 0.06^{\mathrm{b}}$ & $7.81 \pm 0.04^{\mathrm{c}}$ & $10.16+0.06^{\mathrm{c}}$ & $12.13+0.05^{\mathrm{b}}$ \\
\hline 2 & 27 & $1.76+0.01^{\mathrm{b}}$ & $6.60 \pm 0.07^{\mathrm{a}}$ & $8.18+0.05^{\mathrm{b}}$ & $10.42+0.06^{\mathrm{b}}$ & $12.51+0.06^{\mathrm{a}}$ \\
\hline 3 & 5 & $1.84+0.01^{\mathrm{a}}$ & $6.54+0.14^{\mathrm{a}}$ & $8.59 \pm 0.10^{\mathrm{a}}$ & $10.87+0.14^{\mathrm{a}}$ & $12.57 \pm 0.13^{\mathrm{a}}$ \\
\hline
\end{tabular}

$\mathrm{NS}=$ Not significant, $* \mathrm{P}<0.05 ; * * \mathrm{P}<0.01 ; * * * \mathrm{P}<0.001)$

${ }^{\mathrm{a}, \mathrm{b}, \mathrm{c}}$ Means in the same column within a subset having different superscripts are significantly different

$\mathrm{n}=$ sample size

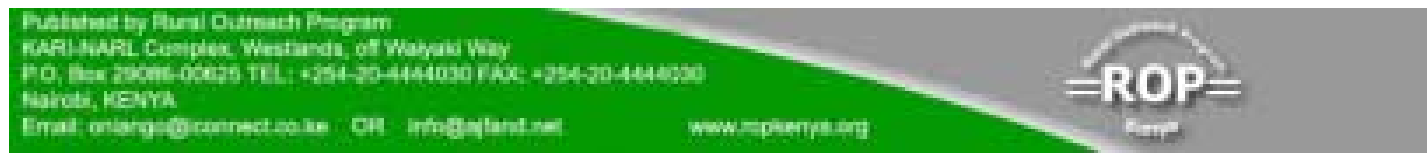




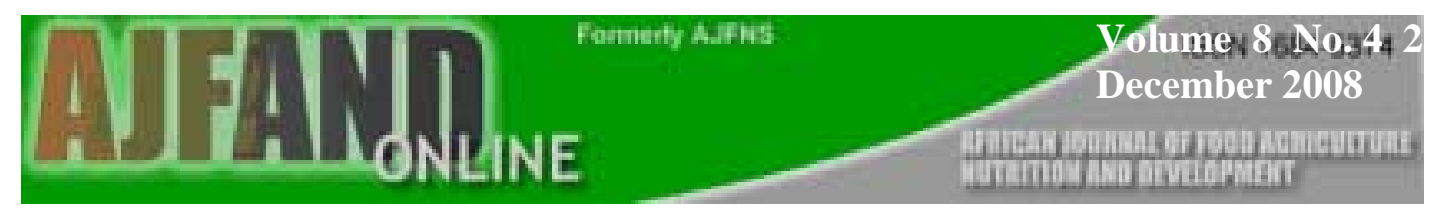

Table 3: $\quad$ Kids mean daily weights gain $(\mathrm{kg} \pm$ S.E $)$ at various ages by breed, body condition score, season, sex, litter size and parity

Age (days)

\begin{tabular}{|c|c|c|c|c|c|}
\hline & $\mathrm{n}$ & Birth -30 & $31-60$ & $61-90$ & $91-120$ \\
\hline Overall & 72 & $153.48 \pm 2.19$ & $58.08 \pm 2.90$ & $77.46 \pm 3.01$ & $65.64 \pm 3.55$ \\
\hline Breed & & $* *$ & $*$ & $\mathrm{NS}$ & $* *-$ \\
\hline Red Sokoto & 29 & $157.05 \pm 2.56^{\mathrm{a}}$ & $56.48 \pm 3.51^{\mathrm{b}}$ & $74.77 \pm 3.33$ & $81.89 \pm 3.96^{\mathrm{a}}$ \\
\hline Sahel & 22 & $156.62 \pm 3.04^{\mathrm{a}}$ & $62.51 \pm 4.08^{\mathrm{a}}$ & $79.48 \pm 4.20$ & $60.39 \pm 5.02^{\mathrm{b}}$ \\
\hline West African Dwarf & 21 & $146.77 \pm 2.63$ & $55.25 \pm 3.42^{\mathrm{b}}$ & $78.14 \pm 3.70$ & $54.64 \pm 4.16^{\mathrm{b}}$ \\
\hline Body condition score & & $* * *-$ & $*$ & $* * *$ & $*-$ \\
\hline 2 & 30 & $147.92 \pm 2.63^{b}$ & $50.94 \pm 3.67^{\mathrm{b}}$ & $75.84 \pm 3.15$ & $58.12 \pm 3.87^{\mathrm{b}}$ \\
\hline 3 & 32 & $153.16 \pm 2.54^{\mathrm{a}}$ & $57.47 \pm 3.48^{\mathrm{ab}}$ & $79.92 \pm 3.86$ & $65.52 \pm 4.87^{\mathrm{a}}$ \\
\hline 4 & 10 & $159.36 \pm 3.81^{\mathrm{a}}$ & $65.83 \pm 4.80^{\mathrm{a}}$ & $76.63 \pm 4.97$ & $73.28 \pm 5.63^{\mathrm{a}}$ \\
\hline Season & & $* * *-$ & $* * *-$ & $* * *$ & $* * *$ \\
\hline Dry & 41 & $157.80 \pm 2.27^{\mathrm{a}}$ & $58.53 \pm 3.04$ & $79.34 \pm 3.04$ & $61.27 \pm 3.54^{\mathrm{b}}$ \\
\hline Wet & 31 & $149.16 \pm 2.69$ & $57.63 \pm 3.52$ & $75.58 \pm 3.73$ & $70.02 \pm 4.47^{\mathrm{a}}$ \\
\hline Sex & & $\mathrm{NS}$ & $\mathrm{NS}$ & $* * *$ & $*$ \\
\hline Male & 33 & $156.11 \pm 2.68$ & $56.46 \pm 3.52$ & $84.71 \pm 3.30^{\mathrm{a}}$ & $70.74 \pm 4.18^{\mathrm{a}}$ \\
\hline Female & 39 & $150.86 \pm 2.72$ & $59.70 \pm 3.68$ & $70.11 \pm 3.95^{\mathrm{b}}$ & $60.54 \pm 4.59^{b}$ \\
\hline Litter size & & $* \quad-$ & $*$ & $\mathrm{NS}$ & $\mathrm{NS}$ \\
\hline 1 & 60 & $157.21+1.84^{\mathrm{a}}$ & $61.19+2.38$ & $75.70+2.48$ & $66.75+2.71$ \\
\hline 2 & 12 & $149.75 \pm 3.49^{b}$ & $54.96+4.69$ & $79.23+4.73$ & $64.54+5.89$ \\
\hline Parity & & $* * *$ & $\mathrm{NS}$ & $\mathrm{NS}$ & $\mathrm{NS}$ \\
\hline 1 & 40 & $141.89+1.86^{\mathrm{b}}$ & $58.37 \pm 2.62$ & $80.11 \pm 2.72$ & $67.60 \pm 3.00$ \\
\hline 2 & 27 & $161.71+2.34^{\mathrm{a}}$ & $52.24+2.94$ & $77.43+2.87$ & $72.28+3.52$ \\
\hline 3 & 5 & $156.85 \pm 4.60^{a}$ & $63.63+6.23$ & $74.84+6.52$ & $57.04+7.53$ \\
\hline
\end{tabular}

$\mathrm{NS}=$ Not significant, $* \mathrm{P}<0.05 ; * * \mathrm{P}<0.01 ; * * * \mathrm{P}<0.001)$

${ }^{\mathrm{a}, \mathrm{b}, \mathrm{c}}$ Means in the same column within a subset having different superscripts are significantly different

$\mathrm{n}=$ sample size

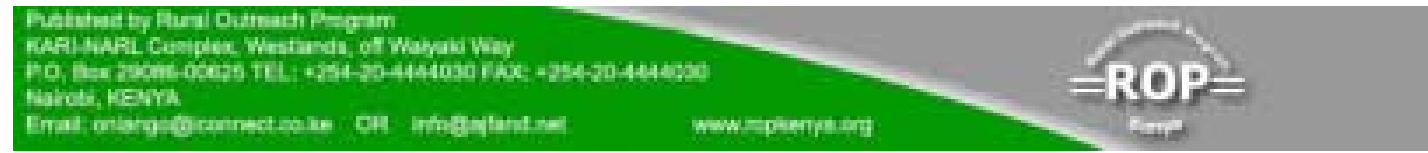




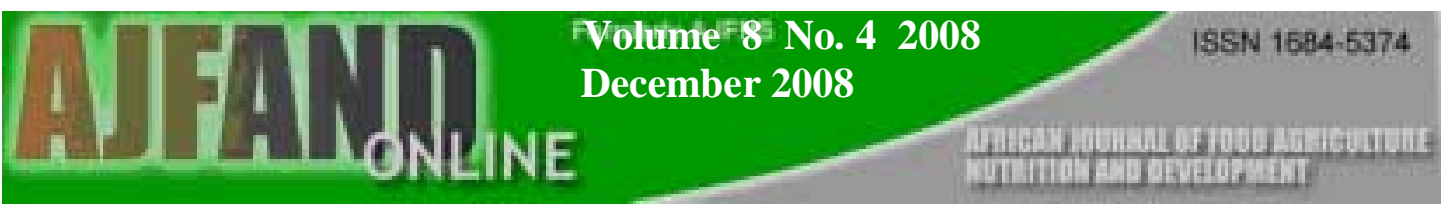

Table 4: $\quad$ Regression equations of some growth traits of Red Sokoto, Sahel and West African Dwarf goats

\begin{tabular}{lll}
\hline Breed & Regression equation & $\mathrm{R}^{2}$ \\
\hline \multirow{2}{*}{ Red Sokoto } & $\mathrm{Y}_{\mathrm{a}}=2.67+0.0857 \mathrm{X}$ & $0.953 * * *$ \\
& $\mathrm{Y}_{\mathrm{b}=141.39-0.654 \mathrm{X}}$ & $0.280^{* * *}$ \\
Sahel & $\mathrm{Y}_{\mathrm{a}}=2.91+0.0862 \mathrm{X}$ & $0.952 * * *$ \\
& $\mathrm{Y}_{\mathrm{b}}=156.76-0.888 \mathrm{X}$ & $0.526 * * *$ \\
West African Dwarf & $\mathrm{Y}_{\mathrm{a}}=2.49+0.0799 \mathrm{X}$ & $0.946 * * *$ \\
& $\mathrm{Y}_{\mathrm{b}}=140.65-0.773 \mathrm{X}$ & $0.418 * * *$ \\
\hline
\end{tabular}

$\mathrm{Y}_{\mathrm{a}}=$ weight, $\mathrm{Y}_{\mathrm{b}}=$ Daily weight gain, $\mathrm{X}=$ age, $* * * \mathrm{P}<0.001$ 


\section{REFERENCES}

1. Adu IF, Buvanendran V and CAM Lakpini The reproductive performance of Red Sokoto goats in Nigeria. J. Agric. Sci. (Camb).1979; 93: 563-566.

2. Osinowo OA Small ruminant statistics, Nigeria Monograph. 1992:1-5.

3. Zahraddeen D Studies on reproductive performance and milk productivity of goats in Bauchi. Ph.D. Thesis, Abubakar Tafawa Balewa University, Bauchi, Nigeria. 2006:210

4. Butswat IS Study on seasonal variation in the reproductive status of sheep and goats in Bauchi. Ph.D. Thesis, Abubakar Tafawa Balewa University, Bauchi, Nigeria.1994:56

5. Butswat ISR, Sir SM and SU Gwani Reproductive performance of small ruminants under the traditional management system in north-eastern Nigeria. Proceedings of the Silver Aniversary Conference of Nigerian Society for Animal Production |(NSAP) held at University of Agriculture, Abeokuta, Nigeria, 1998:532-533.

6. Butswat IS and DT Zahraddeen Comparisons of some reproductive parameters in Red Sokoto and Kano Brown breeds of bucks. Nig. J. Anim. Prod. 1998; 25(1): $1-5$

7. Hill DH Cattle and buffalo meat production in the tropics. First edition, Longman Group, UK,Limited. 1988:210

8. Malau-Aduli BS, Eduvie LO, Lakpini CAM and AEO Malau-Aduli Cropresidue supplementation of pregnant does influences birth weight and weight gain of kids, daily milk yield but not the progesterone profile of Red Sokoto goats. Repro. Nutr. Dev. 2004; 44:111-121.

9. Zahraddeen D, Butswat ISR, Abdulkarim M, Mancha YP and D Yande Birth weights and weaning weights of West African Dwarf lambs and kids under small holder husbandry system in guinea savannah zone of Nigeria. Proceedings of the $32^{\text {nd }}$ Annual Conference of Nigerian Society for Animal Production (NSAP) held at the University of Calabar, Nigeria. 2007: 95.

10. Zahraddeen D, Butswat ISR and ST Mbap Gestation length, kidding interval and reproductive problems in goats in Bauchi, Nigeria. J. Agric. Res,. Policies. 2007; 2(4): 11-16

11 Butswat ISR, Zahraddeen D and AS Hussaini Prevalence of peste de pestits ruminant (PPR) and helminthiasis in sheep and goats in Bauchi, Nigeria. Bull.. Anim. Hlt Prod., Afr. 2005; 53: 131-134. 
12. Ojewola GS and GI Onwuka Evaluation of organoleptic properties of suya produced from various sources of meat. Nig. J. Anim. Prod. 2001; 28(2): 199201

13. Deventra $\mathbf{C}$ and $\mathbf{M}$ Burns Goat production in the tropics: Technical Communication, No. 1 of the CommonWealth Bureau of Animal Breeding and Genetics, Edinburgh, UK, 1970:1-25

14. Merin U, Rosenthal I and E Mattz The composition of goat milk as affected by nutritional parameters. Mtichwissenschaft.1988;43:363-365

15. Odeyinka SM and GK Okunade Goat production in Oyo State: A case study of Ogbomoso town. Nig. J. Anim. Prod. 2005;32(1): 108-115

16. Doma UD, Mohammed IK and AP Umeh Observations on the characteristics of smallholder sheep and goat management practices in old Bauchi State, Nigeria. Trop. J. Anim. Sci. 1999;2:125-130.

17. Kowal JM and DT Knabe Agroclimatological Atlas of the Northern States of Nigeria with explanatory notes. Ahmadu Bello University Press, Zaira, Nigeria. 1972: 128p.

18. Jefferies BC Body condition scoring and its use in management. Tasma. J. Agric. 1961; 32: 19-21

19. Malau-Aduli BS, Eduvie LO, Lakpini CAM and AEO Malau-Aduli Influence of crop residue ration supplementation on the attainment of puberty and postpartum reproductive activities of Red Sokoto does. J. Anim. Physio. Nutr. 2004; 88:1-10.

20. Humburg M Statistical Analysis for Decision Making. $2^{\text {nd }}$ Edition, Harcourt Brace, New York. 1977: 801.

21. Adama TZ and IO Arowolo Body weight and body condition of Yankasa lambs and Savanna Brown kids from birth to 100 days of life. J. Agric. Sci. Techno. 2002; 12 (2):92-96

22. Nkungu DR, Kifaro GC and LA Mtenga Performance of dairy goats, in Mgeta, Morogoro, Tanzania. Srnet Newsletter.1995; 28: 3-8.

23. Otuma MO, Omeje SI, Alaku SO and B Nweze Growth performance of Red Sokoto and West African Dwarf goats fed on native/Esut pastures supplemented with concentrate ration. In: Proceedings of Silver Anniversary Conference of Nigerian Society of Animal Production / West African Society of Animal Production Inaugural Conference, held between March 21-26, Abeokuta, Nigeria. 1998:211. 
24. Malik RC, Singh RN, Acharya RM and OP Dutta Factors affecting lamb survival in cross-breed sheep. Trop. Anim. Hlth. Prod. 1980; 12:217-223.

25. Taiwo BBA, Buvanendran $\mathbf{V}$ and IF Adu Effects of body condition on the reproductive performance of Red Sokoto goats. Nig. J. Anim. Prod. 2005; 32(1): $1-6$.

26. Kiango SM Some features influencing performance of dairy goats at Magadu Farm.B.Sc. Agriculture Special Project, Sokoine University of Agriculture, Morogoro, Tanzania.1989:55

27. Setchell BP, Waites GMH and HR Lindner Effect of under-nutrition on testicular body flow and metabolism and the output of testosterone in the ram. $J$. Reprod. Fert. 1965; 9: 149-157.

28. Charan C Goat production and development in Thailand. Proceedings of International Seminar on Recent Improvement in Goat Production in Asia, Kasetsart University, Bangkok/10900, Thailand.1984:61

29. Wilson RT Reproductive performance of African indigenous small ruminants under various management systems: A Review. Anim. Prod. Sci.1989; 19: 523529.

30. Bemji MN, Osinowo OA, Ozoje MO, Adebambo OA and ABJ Aina Live weight changes during lactation and its relationship with milk off take and yield in West African Dwarf and Red Sokoto goats intersively managed within the humid zone of Nigeria. Nig. J. Anim. Prod. 2006; 33 (1): 145-150

31. Osinowo OA and IF Adu Intensive sheep production. National Animal Production Research Institute (NAPRI), ABU, Zaria, Nigeria. 1985:45

32. Akanno EC and SN Ibe Prediction of body weight of the domestic rabbit at different stages of growth using linear body measurements. Nig. J. Anim. Prod. 2006; 33 (1): 3-8.

33. Zahraddeen D, Butswat ISR and ST Mbap Goat production and management in Bauchi State, Nigeria. Proceedings of the 21 st Annual National Conference of Farm Management Association of Nigeria |(FAMAN) held at Olabisi Onabanjo University, Ogun State, Nigeria. 2007:231-240. 